\title{
Temperature Effect on Performance of Different Solar Cell Technologies
}

\author{
Jehad Adeeb' ${ }^{1}$ Alaa Farhan², Ahmed Al-Salaymeh³ \\ 1 Renewable Energy Center, Applied Science Private University, Amman 11931, Jordan \\ 2 Mechanical Engineering Department, Zarqa Private University, Az-Zarqa 13132, Jordan \\ 3 Mechanical Engineering Department, School of Engineering, The University of Jordan, Amman 11942, Jordan \\ * Corresponding author's e-mail:__adeeb@asu.edu.jo
}

\begin{abstract}
One of the main parameters that affect the solar cell performance is cell temperature; the solar cell output decreases with the increase of temperature. Therefore, it is important to select the proper solar cell technology that performs better at a specified location considering its average temperatures. In addition, the solar cell performance is directly reflected on the overall economics of the project. This paper is proposed to evaluate the variations in the performance of different solar cell technologies related to the temperature in Amman, Jordan. Field data of weather station and three PV systems (Poly-crystalline, Mono-crystalline and Thin-film) of identical design parameters were collected from Test Field Project at Applied Science Private University, Shafa Badran, Amman, Jordan. These data were analysed in the following way. estimated specific energy yield $(\mathrm{kWh} / \mathrm{kWp})$ for the three different PV systems was calculated depending on the measured value of solar irradiance and technical specifications of the installed solar panels and inverters, then the actual energy yield at different temperatures over one year was compared with the estimated value, so the deviations could be determined and actual temperature coefficients for energy yield could be calculated, knowing that the three PV Systems have identical design parameters (tilt angle, azimuth angle, type and dimensions of mounting structure and inverter size) and same cleaning method and schedule. It was found that the thin-film solar panels are less affected by temperature with temperature coefficient of $-0.0984 \%$, and $-0.109 \%$, $-0.124 \%$ for Mono-crystalline and Poly-crystalline respectively. These results can be implemented in the preliminary design steps, specifically in the selection of the solar cell technology to be installed in a specific location.
\end{abstract}

\section{INTRODUCTION}

Solar cells directly convert sunlight into electricity, as a result of the photovoltaic effect and the fact they consist of doped semiconductor materials forming a P-N Junction. Different semiconductor materials can be used in solar cells, including Crystalline Silicon (c-Si) and Amorphous Silicon (a-Si). The c-Si can be either Polycrystalline or Mono-crystalline, depending on the manufacturing processes implemented.

The solar cell performance is directly affected by the weather conditions, mainly the solar irradiance and temperature [Sauer et al. 2007]. The effect of decreasing irradiance involves a drop in solar cell output current and voltage, and the effect of increasing cell temperature consists in a slight increase in the output current and considerable decrease in output voltage, resulting in an overall decrease in output power. These effects are illustrated in Figures 1 and 2.

Solar panels are tested in laboratory setting under Standard Test Conditions (STC) of $1000 \mathrm{~W} / \mathrm{m}^{2}$ incident solar irradiance, $25^{\circ} \mathrm{C}$ cell temperature, 0.0 wind speed and 1.5 air mass spectrum. STC rarely exist in actual outdoor conditions, specifically the cell temperature, since most of the time, under actual operating conditions, will be much higher than $25^{\circ} \mathrm{C}$, especially in hot climates [Pless et al. 2005]; hence, they cannot be used to estimate the actual performance and energy yield of a PV System.

Different solar cell technologies have different responses to the temperature variations, and 


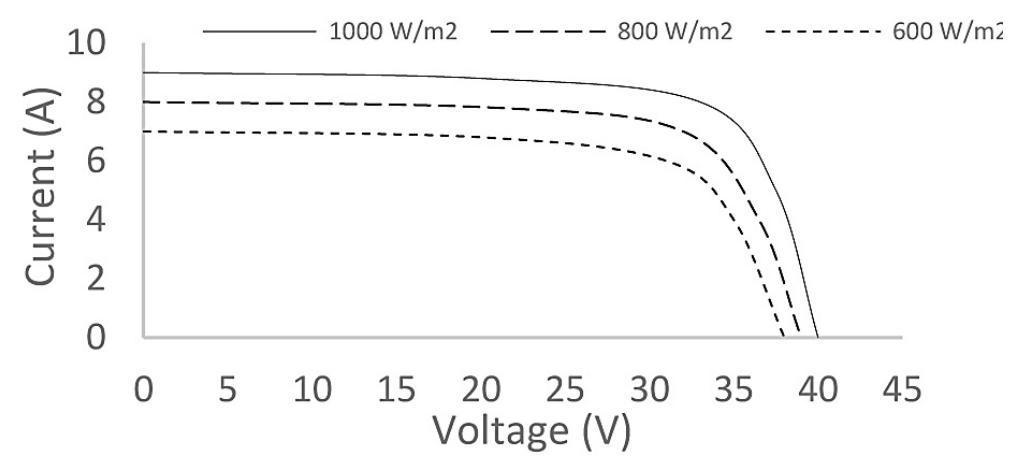

Figure 1. Effect of Irradiance on Solar Cell I-V Curve

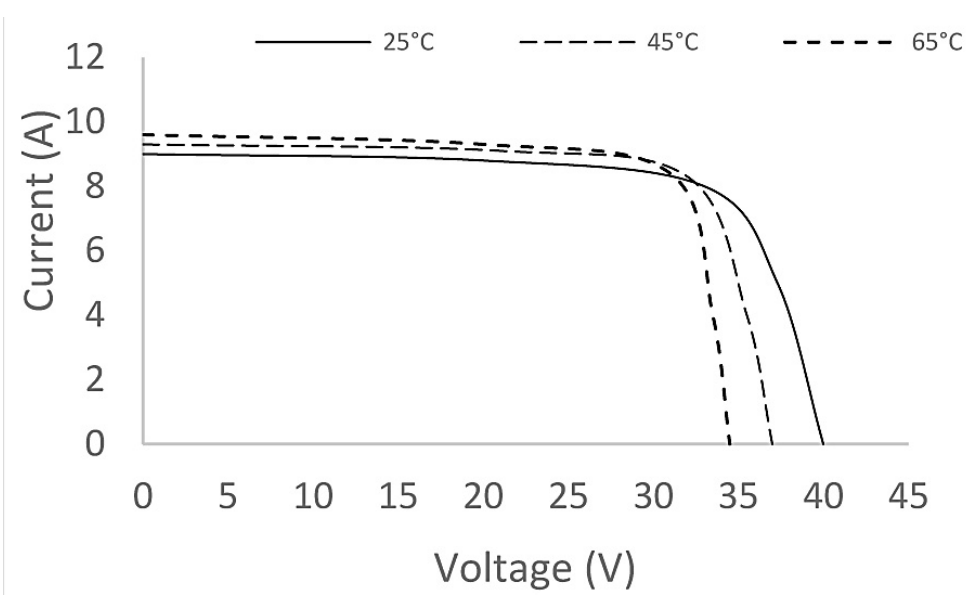

Figure 2. Effect of Temperature on Solar Cell I-V Curve

this difference in response has been widely investigated in the literature.

Hamrouni et al. [2008] investigated the effect of ambient temperature and solar irradiance on the performance of solar pumping system and concluded that high ambient temperature decreased the pump flow rate and overall system efficiency. Priyanka and Ravindra [2012] studied the temperature dependence (in the range of 273-523 K) of key characteristics of solar cell, namely the short circuit current density, open circuit voltage, fill factor and efficiency, considering solar cells of different semiconductor materials such as. Si, GaAs, InP, CdTe and CdS. They concluded that the overall performance decreases with the increase of temperature.

Dubey et al. [2013] reviewed literature investigations on the relation between cell temperature and solar cell performance, and concluded that care must be taken when using the expressions found in the literature to estimate solar cell temperature, because those expressions apply only for restricted mounting geometry. Tobnaghi et al. [2013] experimentally obtained coefficients to estimate the variations in the electrical parameters of solar cells with temperature, and the most significant coefficient obtained described the decrease of maximum power output with the increase of temperature, with coefficient of $-0.005 \mathrm{~mW} /{ }^{\circ} \mathrm{C}$.

Je et al. [2014] monitored the performance of different solar cell technologies in tropical climate in Singapore, including mono-crystalline $\mathrm{Si}$, heterojunction crystalline $\mathrm{Si}$, multicrystalline $\mathrm{Si}$, double-junction $\mathrm{Si}$, single-junction/double-junction amorphous $\mathrm{Si}, \mathrm{CdTe}$ and CIGS. In this work, the degradation rates were evaluated using Statistical decomposition methods. The degradation rates for mono-crystalline Si modules were found to be equal or less than $-0.8 \%$ per year, $-1 \%$ for multicrystalline Si modules, $-2 \%$ for amorphous $\mathrm{Si}$, micromorph $\mathrm{Si}$, and $\mathrm{CdTe}$ modules and $-6 \%$ for CIGS modules.

Cañete et al. [2014] studied the performance of four different technologies in southern Spain; it was found that the performance of thin-film modules is better in summer, while in the case of poly-crystalline modules, their performance is better in winter.

This paper investigates the temperature effect in Amman, Jordan, on mono-crystalline, 
poly-crystalline and a-Si modules, through estimating the effect on annual energy yield. The actual temperature coefficients are calculated and compared to the coefficients in the datasheets of the solar panels. This work is useful in the preliminary design steps of a PV Systems, specifically in the selection of module technology to be implemented in the project.

\section{DESCRIPTION OF PV SYSTEMS AND ANALYSED DATA}

\section{PV Systems}

Test Field Project at Applied Science Private University (ASU) is a unique project of its type in Jordan, with its diverse installed PV System. The project comprises seven different PV projects, all installed for research purposes. These systems are. CPV Dual-Axis Tracking System, Poly-crystalline Dual-Axis Tracking System, South Poly-crystalline PV System (S-Poly), South Mono-crystalline PV System (S-Mono), South Thin-film PV System (S-Thin-film), EastWest Poly-crystalline PV System and East-West Mono-crystalline PV System. This diversity in the project offers wide research capabilities for the project, and the three south oriented PV Systems were chosen for the purpose of analysis in this paper, knowing that they are all of identical design parameters (tilt angle, azimuth angle, type and dimensions of mounting structure, length and gauge of wiring and inverter size). Technical specification of inverters and PV panels for the three systems are described in Table 1 and Table 2. Identical design parameters are outlined in Table 3. The three systems and weather station, which is $70 \mathrm{~m}$ apart from the PV Systems, are shown in Figures 3 to 6.

\section{Weather Station}

In addition to these three systems, the weather data were also collected from a standardized weather station in ASU offering wide range of

Table 1. Technical Specifications of the Inverters

\begin{tabular}{|c|c|c|c|}
\hline System & Model & $\begin{array}{c}\text { Size } \\
\left(\mathrm{kW}_{\mathrm{AC}}\right)\end{array}$ & $\begin{array}{c}\text { Max. } \\
\text { efficiency }\end{array}$ \\
\hline S-Poly & SB 5000TL-20 & 5 & $97 \%$ \\
\hline S-Mono & SB 5000TL-20 & 5 & $97 \%$ \\
\hline S-Thin-film & SMC 5000A & 5 & $96.1 \%$ \\
\hline
\end{tabular}

measured data (Figure 7) such as. ambient temperature at different levels, global, direct and diffused irradiance, wind speed and direction at different levels. Irradiance and ambient temperature at $1 \mathrm{~m}$ level above the ground are used in this paper for the purpose of analysis.

\section{METHODOLOGY AND CALCULATIONS}

\section{Methodology}

Since all the three PV Systems are of identical design parameters and exposed to same weather conditions (irradiance, temperature and wind speed), we can assume that the difference between the actual energy yield $(\mathrm{kWh} / \mathrm{kWp})$ and estimated energy yield is primarily due to actual cell temperature $\left(\mathrm{T}_{\mathrm{c}}\right)$ being higher (or lower) than $\mathrm{T}_{\mathrm{c}}$ at STC, taking into account the actual incident irradiance, array size $(\mathrm{kWp})$, array area and module as well as inverter efficiency.

\section{Data and Calculations}

The actual data for energy yield were extracted from the monitoring system of the three inverters and are shown in Table 4. In Table 5, average monthly values for ambient temperature $\left(\mathrm{T}_{\mathrm{a}}\right)$ and global horizontal irradiance (GHI) is extracted from the weather station data logger. Direct horizontal irradiance (DHI) is calculated using Diffused/Global irradiance ratio in [PVGIS

Table 2. Technical Specifications of the PV Panels

\begin{tabular}{|l|c|c|c|}
\hline $\begin{array}{c}\text { Module } \\
\text { technology }\end{array}$ & $\begin{array}{c}\text { Mono- } \\
\text { crystalline }\end{array}$ & $\begin{array}{c}\text { Poly- } \\
\text { crystalline }\end{array}$ & Thin-film \\
\hline Model & YL260C-30b & YL250P-29b & NA-E125L5 \\
\hline $\mathrm{P}_{\max }(\mathrm{STC})$ & $260 \mathrm{~W}$ & $250 \mathrm{~W}$ & $125 \mathrm{~W}$ \\
\hline Dimensions & $1.65 \times 0.99 \mathrm{~m}$ & $1.65 \times 0.99 \mathrm{~m}$ & $1.40 \times 1.00 \mathrm{~m}$ \\
\hline Efficiency & $15.9 \%$ & $15.3 \%$ & $8.9 \%$ \\
\hline $\begin{array}{l}\text { Temp. } \\
\text { Coefficient } \\
\text { for } \mathrm{P}_{\max }\end{array}$ & $-0.42 \% /{ }^{\circ} \mathrm{C}$ & $-0.45 \% /{ }^{\circ} \mathrm{C}$ & $-0.24 \% /{ }^{\circ} \mathrm{C}$ \\
\hline $\begin{array}{l}\text { Number of } \\
\text { Modules } \\
\text { installed }\end{array}$ & 20 & 20 & 40 \\
\hline
\end{tabular}

Table 3. Identical Design Parameters

\begin{tabular}{|l|l|}
\hline Tilt angle & $11^{\circ}$ \\
\hline Azimuth angle & $0^{\circ}$ (Directly south oriented) \\
\hline Type of Mounting Structure & $\begin{array}{l}\text { Ground Mounted (Elevated } \\
\text { Structure) }\end{array}$ \\
\hline
\end{tabular}




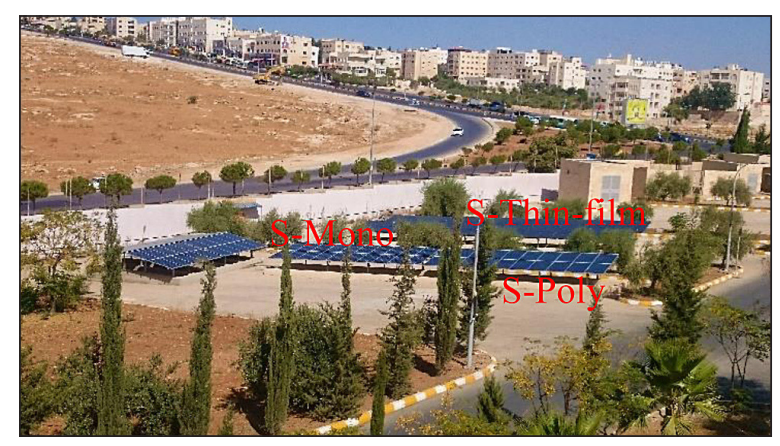

Figure 3. PV Systems

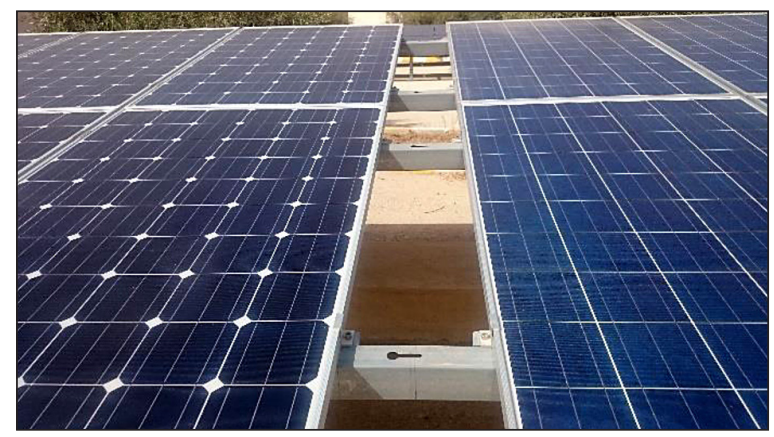

Figure 4. S-Mono (left), S-Poly (right)

European Communities, 2001-2012]. The data of wind speed is neglected, since $T_{c}$ is taken into account in the calculations, and $\mathrm{T}_{\mathrm{c}}$ is directly affected by wind speed [Dubey 2013].

Estimated energy yield $(\mathrm{kWh} / \mathrm{kWp} /$ month) can be calculated using equation 1 .

$$
E_{\text {estimated }}=G \times A \times \eta \times t / P_{\max }
$$

where: $G$ is average monthly global incident irradiance $\left(\mathrm{kW} / \mathrm{m}^{2}\right)$,

$A$ is array total area $\left(\mathrm{m}^{2}\right)$,

$\eta$ is module efficiency,

$t$ is total number of hours per month and $P_{\max }$ is array maximum power $(\mathrm{kWp})$. Global incident irradiance is calculated using the following formula [Gulin et al. 2013] and solar angles in [PVSyst V6.43] form PVSyst software.

$$
G=B+D+R
$$

\section{RESULTS AND CONCLUSION}

Where $B$ is direct irradiance in tilted and aligned surface, $D$ is diffuse irradiance on tilted and aligned surface and $R$ is reflection irradiance on tilted and aligned surface. In the calculations,

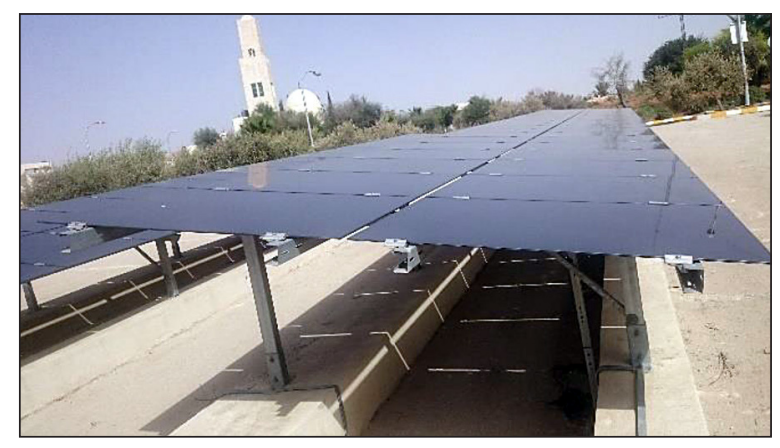

Figure 5. S-Thin-film

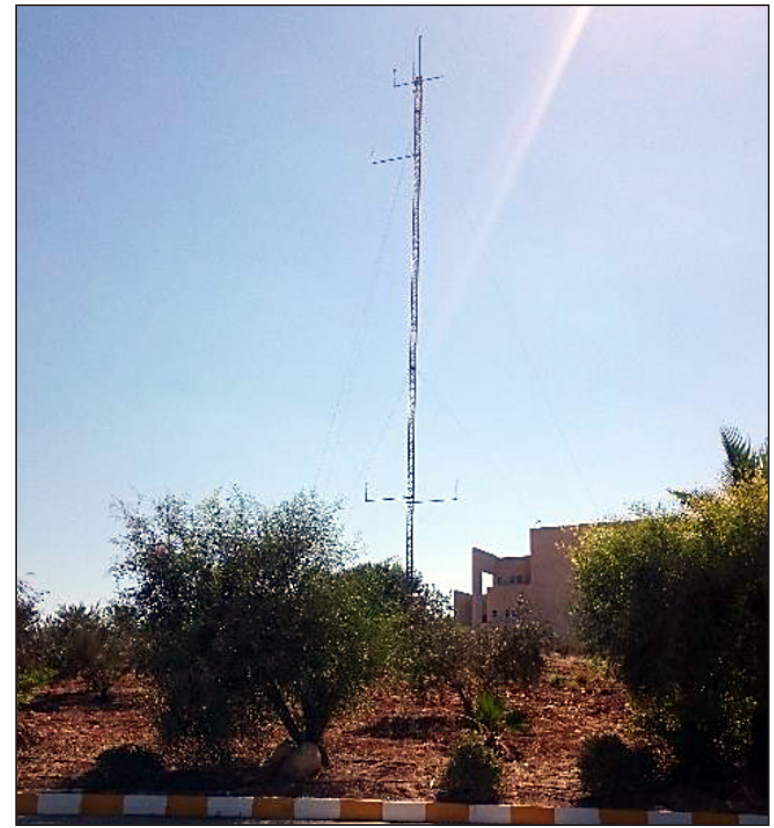

Figure 6. ASU Weather Station

$D$ and $R$ are assumed as one component since a pyranometer measures both together. Table 6 shows the results of applying equations 1 and 2 .

Calculating $T_{c}$ is critical in determining the amount of deviation between the actual and theoretical energy yield at STC. Hence, $\mathrm{T}_{c}$ is calculated using the formulae found in [SMA Solar Academy], which simply states that if the module is free mounted (ground mounted), $\mathrm{T}_{\mathrm{c}}$ will be $20^{\circ} \mathrm{C}$ higher than the ambient temperature. Therefore, annual average increase in calculated $\mathrm{T}_{\mathrm{c}}$ over $\mathrm{T}_{\mathrm{c}}$ at STC was found to be $12.53^{\circ} \mathrm{C}$.

Annual deviation in energy yield for the three systems was found to be $15.4 \%, 17.0 \%$ and $19.5 \%$ for Thin-film, Mono-crystalline and Poly-crystalline PV modules, respectively. This amount of deviation is assumed to be caused by temperature rise of $12.53^{\circ} \mathrm{C}$ in $\mathrm{T}_{c}$. Then, the deviation caused by temperature rise of $1{ }^{\circ} \mathrm{C}$ in $\mathrm{T}_{\mathrm{c}}$ was calculated. 


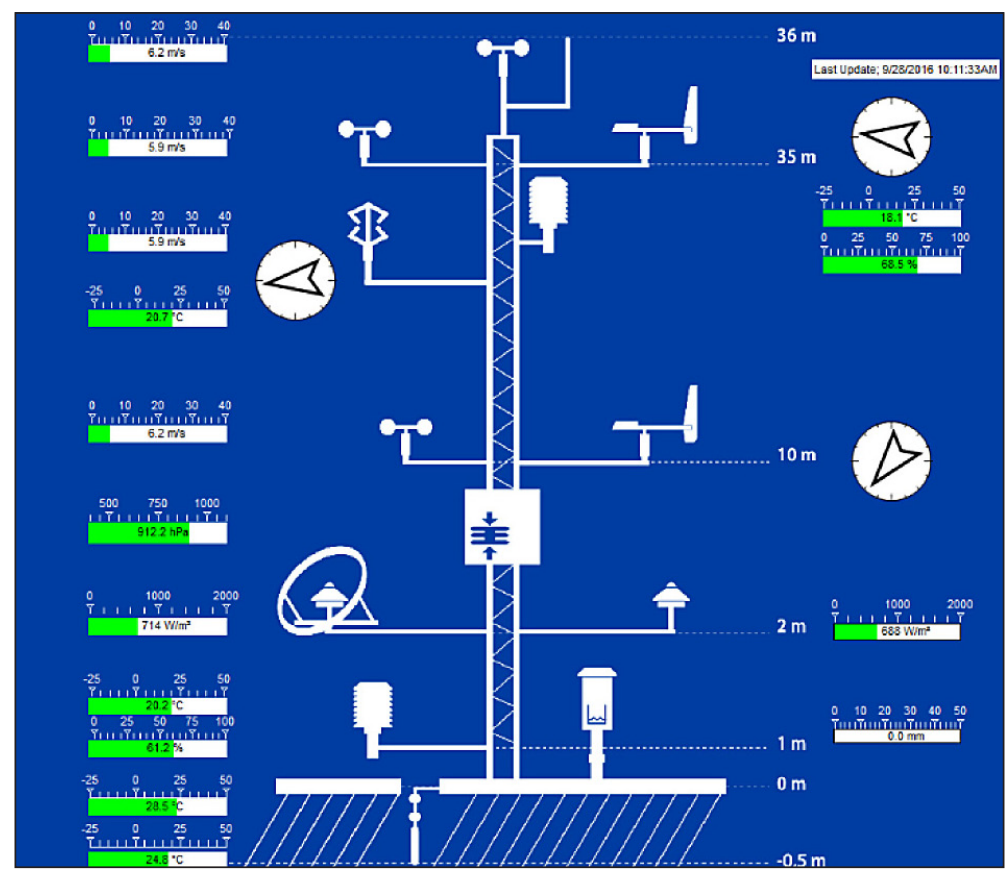

Figure 7. Data of ASU Weather Station

Table 4. Actual Energy Yield (kWh/kWp/month)

\begin{tabular}{|c|c|c|c|}
\hline Month & S-Mono & S-Poly & S-Thin-film \\
\hline January & 91.52 & 87.73 & 84.84 \\
\hline February & 122.68 & 118.21 & 118.35 \\
\hline March & 144.03 & 139.85 & 140.74 \\
\hline April & 172.41 & 168.53 & 176.11 \\
\hline May & 182.01 & 179.5 & 191.62 \\
\hline June & 192.65 & 190.5 & 201.94 \\
\hline July & 198.04 & 194.68 & 209.45 \\
\hline August & 186.23 & 181.28 & 197.11 \\
\hline September & 159.69 & 153.5 & 166.66 \\
\hline October & 146.54 & 139.48 & 150.69 \\
\hline November & 110.01 & 104.24 & 105.92 \\
\hline December & 86.15 & 83.02 & 79.29 \\
\hline
\end{tabular}

The results demonstrated that energy yield for Thin-film PV modules is less affected by temperature than Mono-crystalline and Poly-crystalline PV modules. Temperature coefficient for Thin-film PV modules was found to be $-0.0984 \%$, which means that for each $1^{\circ} \mathrm{C}$ of $\mathrm{T}_{c}$ increase above that of $\mathrm{T}_{c}$ at STC, the energy yield will decrease by $0.0984 \%$. For Mono-crystalline and Poly-crystalline PV modules, temperature coefficient was found to be $-0.109 \%$ and $-0.124 \%$, respectively.

These results are good indications of how ambient temperature would affect the annual energy yield of a PV System, and they are of increasing importance for large-scale PV projects since the decrease of energy yield with temperature will be of greater amount.
Table 5. Average Monthly Weather Data

\begin{tabular}{|c|c|c|c|}
\hline Month & $\mathrm{T}_{\mathrm{a}}\left({ }^{\circ} \mathrm{C}\right)$ & $\mathrm{GHI}\left(\mathrm{W} / \mathrm{m}^{2}\right)$ & $\mathrm{DHI}\left(\mathrm{W} / \mathrm{m}^{2}\right)$ \\
\hline January & 6.8 & 116 & 67 \\
\hline February & 11.5 & 182 & 106 \\
\hline March & 13.1 & 212 & 127 \\
\hline April & 19.4 & 285 & 182 \\
\hline May & 19.9 & 302 & 214 \\
\hline June & 25.5 & 349 & 269 \\
\hline July & 25.1 & 344 & 265 \\
\hline August & 24.9 & 299 & 227 \\
\hline September & 22.3 & 262 & 194 \\
\hline October & 20.2 & 196 & 135 \\
\hline November & 14.2 & 150 & 99 \\
\hline December & 7.5 & 109 & 68 \\
\hline
\end{tabular}

Table 6. Global Incident Irradiance and Estimated Energy Yield for PV Systems

\begin{tabular}{|c|c|c|c|c|}
\hline \multirow{2}{*}{ Month } & \multirow{2}{*}{$\begin{array}{c}\mathrm{k}(\mathrm{kW} / \\
\left.\mathrm{m}^{2}\right)\end{array}$} & \multicolumn{3}{|c|}{$\mathrm{E}_{\text {estimated }}(\mathrm{kWh} / \mathrm{kWp} / \mathrm{month})$} \\
\cline { 3 - 5 } & S-Mono & S-Poly & S-Thin-film \\
\hline January & 131 & 97 & 97 & 97 \\
\hline February & 199 & 138 & 139 & 138 \\
\hline March & 225 & 167 & 167 & 167 \\
\hline April & 294 & 212 & 212 & 211 \\
\hline May & 306 & 228 & 228 & 227 \\
\hline June & 351 & 253 & 253 & 252 \\
\hline July & 348 & 259 & 259 & 258 \\
\hline August & 309 & 229 & 230 & 229 \\
\hline September & 279 & 201 & 201 & 200 \\
\hline October & 216 & 160 & 160 & 160 \\
\hline November & 171 & 123 & 123 & 123 \\
\hline December & 126 & 94 & 94 & 93 \\
\hline
\end{tabular}




\section{Acknowledgments}

The authors wish to thank Applied Science Private University for the valuable data provided.

\section{REFERENCES}

1. Cañete C., Carretero J. and Sidrach-de-Cardona M., 2014. Energy performance of different photovoltaic module technologies under outdoor conditions", Energy, 65, Feb., 295-302.

2. Dubey S., Sarvaiya J.N. and Seshadri B. 2013. Temperature Dependent Photovoltaic (PV) Efficiency and Its Effect on PV Production in the World, A Review. Energy Procedia, 33, 311-321.

3. Gulin M., Vašak M. and, Baotić M., 2013. Estimation of the global solar irradiance on tilted surfaces. Proc. of 17th International Conference on Electrical Drives and Power Electronics, EDPE 2013, 334-339.

4. Hamrouni N., Jraidi M. and Chérif A., 2008. Solar radiation and ambient temperature effects on the performances of a PV pumping system", Revue des Energies Renouvelables, 11(1), 95-106.

5. Pless S., Deru M., Torcellini P., and Hayter S. 2005. Procedure for Measuring and Reporting the Performance of Photovoltaic Systems in Buildings. Colorado. DOE/NREL and MRI, pp. 4.
6. Priyanka S. and Ravindra N.M., 2012. Temperature dependence of solar cell performance-an analysis, Solar Energy Materials and Solar Cells, 101, 36-45.

7. PVGIS European Communities, 2001-2012, Monthly Solar Radiation Data, D/G. Ratio of diffuse to global irradiation, 32.040, 35.900. http.//re.jrc. ec.europa.eu/pvgis/apps4/pvest.php?map=africa

8. PVSyst V6.43. Tools, Tables/graphs of solar parameters, Sun height and Incidence angle at $0^{\circ}$ azimuth and $11^{\circ}$ tilt in Shafa Badran, Jordan.

9. Sauer D., Rau U. and Kaltschmitt M. 2007. Photovoltaic Power Generation. In: Kaltschmitt M., Streicher W. and Wiese A (Eds.), Renewable Energy - Technology, Economics and Environment. Berlin/Heidelberg. Springer-Verlag Publishing, pp. 268-271.

10. SMA Solar Academy. Planning and Design, M-PPD-1-DE-en_WW-123610, pp. 18.

11. Tobnaghi D.M., Madatov R. and Naderi D., 2013. The effect of temperature on electrical parameters of solar cells. International Journal of Advanced Research in Electrical, Electronics and Instrumentation Engineering, 2(12).

12. Ye J.Y., Reindl T., Aberle A.G. and Walsh T.M., 2014. Performance Degradation of Various PV Module Technologies in Tropical Singapore", IEEE Journal of Photovoltaics, 4(5), Sept. 